Chapman University

Chapman University Digital Commons

$11-19-2021$

Using Sociological Images to Develop the Sociological

Imagination

Georgiana Bostean

Lisa A. Leitz

Follow this and additional works at: https://digitalcommons.chapman.edu/sociology_articles

Part of the Curriculum and Instruction Commons, Curriculum and Social Inquiry Commons, Other Sociology Commons, Social Psychology and Interaction Commons, and the Sociology of Culture Commons 


\section{Using Sociological Images to Develop the Sociological Imagination}

\section{Comments}

This is a pre-copy-editing, author-produced PDF of an article accepted for publication in Teaching Sociology in 2021 following peer review. The definitive publisher-authenticated version is available online at https://doi.org/10.1177/0092055X211054572.

\section{Copyright}

The authors 
Running Head = SOCIOLOGICAL IMAGES

Manuscript ID: TS-17-0036.R3

Using Sociological Images to Develop the Sociological Imagination

Georgiana Bostean

Chapman University

Lisa Leitz

Chapman University

ACCEPTED FOR PUBLICATION IN TEACHING SOCIOLOGY

Corresponding Author

Georgiana Bostean, One University Drive, Orange, CA 92866

Email: gbostean@chapman.edu 


\begin{abstract}
We present a two-assignment series that developed students' sociological imaginations and that could be done in a face-to-face or online course. The series used the Sociological Images blog and students' own visual images (e.g., photographs) to meet course learning goals: (1) link sociological theories and concepts to social events/trends, (2) apply these ideas to real life by identifying sociologically relevant images in daily life, and (3) communicate sociological analysis in academic and popular written forms. The use of a blog encourages students to embrace public sociology. We present faculty and student assessment data (pretest from nonequivalent comparisons group) from six lower division sociology classes at a regional university $(\mathrm{N}=157)$. Students entered with little a priori ability to examine images using a sociological lens, and students who completed the series successfully applied sociological concepts and theories to critically examine elements of their lives, achieving core sociology disciplinary learning goals.
\end{abstract}

\title{
Keywords
}

critical thinking, introductory sociology, learning outcomes, sociological imagination, visual sociology 
Core learning goals of lower division sociology courses include the ability to understand the relevance and reality of structural factors in social life, and to place issues in a larger context (Persell 2010). Achieving these goals requires students to develop their sociological imaginations - the capacity to see the impact of broader social forces on individual lives (Mills 1959). Students tend to perceive things as individual phenomena, and C. Wright Mills' sociological imagination is often among the first sociological perspectives to which students are exposed (Ghidina 2019; Scanlan and Grauerholz 2009). How to effectively develop students' sociological imagination is an important pedagogical issue, as evidenced by its attention in the scholarship of teaching and learning sociology (Bidwell 1995; Brouillette and Turner 1992; Huisman 2010; Trautner and Borland 2013). However, there are few examples of teaching strategies for to effectively develop students' sociological imaginations or assessing this learning.

In this article, we offer a novel two-part visual sociology assignment series with learning goals related to the sociological imagination and public sociology, along with multiple assessments that demonstrate its effectiveness. We designed this series based on pedagogical literature, particularly situated learning theory and research on active learning (Bonwell and Eison 1991), which suggest that students engage in higher order thinking and learn better when concepts are contextualized and made applicable. This assignment series embeds the sociological imagination into the course (Rogers, Nemeroff, and Caputo 2019), and encourages active learning by using visual media and a blog and allowing students to exercise their sociological analytical skills beyond the classroom and books - actively engaging in, rather than simply reading about sociology. Being based on digital media, the assignment series is particularly useful in the current teaching and learning context, as many courses have shifted online due to 
the COVID-19 pandemic. Given the simplicity of the assignment with its use of one blog site and use of photos, it is accessible to most students, avoiding the problem of overestimating student knowledge of and access to technology (Gillis and Krull 2020; Kozimor 2020).

The series comprises two complementary assignments, designed based on pedagogical insights from the visual sociology field, scholars' illumination of how to cultivate that thought process through classroom assignments, and Mills' discussion of how to stimulate the sociological imagination. In the first assignment, ${ }^{1}$ students critically analyzed and expanded on posts from the Sociological Images website, which is a useful tool for sociology courses (Mayeda 2010; Wade and Sharp 2013). In the second assignment, students found their own images in their daily lives, such as advertisements they encountered, photos from inside a shopping mall or their dormitories, or images from internet or social media sites. The series (described in detail below) was used in six lower division courses $(\mathrm{N}=157$ students) at a primarily undergraduate institution, and honed over four semesters to best meet learning objectives.

\section{Pedagogical Approach and Contributions}

Our assignment series contributes to the scholarship of teaching and learning in several ways. First, it uses a public sociological blog to introduce students to seeing the world through a sociological lens and allows them to practice sociological writing for a public audience. In doing so, this assignment attempts to address the issue, noted by Hudd (2012), that many sociologists' teaching has not caught up to the social media-immersed world in which our students now live. The writing components allow students to develop their writing skills, both formal and informal, as well as higher-level thinking skills (Massengill 2011). Students with exceptional projects can be encouraged to submit their work to Sociological Images, which is a unique way for students 
to engage in public sociology themselves, something that scholars have noted happens all too rarely (Greenberg, London, and McKay 2019). Few assignments that address Mills' discussion of the sociological imagination foster the skills to write for a public audience.

Second, the project series utilizes a scaffolding approach, with an assignment that first introduces students to sociological analysis, followed by a final project that encourages students to apply sociological knowledge to relevant "images" they discover in their own lives. Instructor expectations increase between the assignments, and the assessments of learning goals and grades demonstrate student learning rather than pre-existing student competency. These elements allow the project series to meet common learning goals of both lower division courses and sociology majors broadly.

Third, by introducing students to social science data collection, we go beyond existing studies that propose assignments to develop the sociological imagination. Similar to other “object-based learning" approaches (Noy and Hancock 2020), the assignment gives students the opportunity to become producers of knowledge by identifying a relevant image on their own and writing a sociological analysis of the image. Although a few images would not be enough for a systematic study, the students are trained to examine the world as observers and to consider it in a scientific manner. This project prepares students for forthcoming sociological courses involving data collection and analysis.

In addition to the contributions of the project series itself, this article provides assessment data that goes beyond the no-comparisons-group design which dominates the literature. To assess learning resulting from the project, we present both instructor evaluation of learning goal fulfillment and grades, along with student impressions in our systematic assessment of the series' learning outcomes. We also provide pretest data related to our learning goals using a 
nonequivalent-comparison-groups design—information which relatively few studies provide (Sweet and Cardwell 2016) — which provided evidence that very few students have the ability to apply the sociological imagination to analyze images early on in introductory sociology courses. By contrast, following the use of the assignment, the majority of students developed the ability to apply a sociological imagination in analysis.

We begin by reviewing literature that led to the development of this assignment series, and which led us to hypothesize that this assignment series would foster students' sociological imagination. Next, we describe the assignment series and our research methods. We then systematically, for each learning goal, assess the effectiveness of the project, providing examples

of student work, instructor and student feedback, and student grades. Finally, we discuss how the series can be tailored for a variety of sociology courses, and potential improvements for the series.

\section{BACKGROUND}

\section{Sociology Learning Goals and the Sociological Imagination}

At the heart of teaching sociology is an interest in expanding the sociological imagination. According to a report by the American Sociological Association (ASA) Task Force on the Undergraduate Major, one of the learning goals for the sociology major is the development of students' sociological imagination, which involves learning and applying sociological principles and concepts to one's own life (McKinney et al. 2004). Another learning goal is developing students" capability to determine "how societal and structural factors influence individual behavior and the self's development" (McKinney et al. 2004:52). Updating this work for the ASA, Pike et al. (2017) suggest that departments utilize the Sociological Literacy Framework 
(Ferguson and Carbonaro 2016), which suggests a key competency within sociology is applying the sociological imagination. Additionally, it encourages introducing the following concepts in introductory courses: the sociological eye (related to the sociological imagination), social structure, socialization, stratification, and social change/reproduction (Ferguson and Carbonaro 2016; Pike et al. 2017). For introductory sociology courses, the top two learning goals as rated by leaders in the field are: (1) To show the relevance and reality of structural factors in social life; and, (2) To place an issue in a larger context (Persell 2010).

The assignment series presented here is designed for courses at the beginning of the sociology major to meet three central learning goals: (1) associate sociological concepts with current social trends, (2) relate these ideas to students' daily lives, and (3) apply sociological analysis in a publicly available format. These learning goals align closely with C. Wright Mills' description of the sociological imagination, which he noted can be cultivated, but "seldom occurs without a great deal of often routine work," (Mills 1959:7) and which must not remain in the realm of "abstract empiricism." Sociologists agree that developing an understanding of "biography in history," or the ability to see the impact of broad social and historical forces on one's own life, is central to sociological learning, making this a focus of much of sociologists' pedagogical literature due the difficulty in achieving this goal. Sociology instructors must find effective ways of achieving sociology learning goals. This assignment series, by using digital and visual tools and specifically a public blog, is an innovative way to do so.

\section{Visual Sociology: Using Sociological Images to Develop the Sociological Imagination}

The use of visual and social media, which is increasing and widespread among young adults, with 90 percent having used social media in 2015 (Perrin 2015). This provides an opportunity to leverage students' familiarity with digital media to help students develop a pattern of critically 
analyzing the social world in which they are frequently engaged. An increasing body of research supports the effectiveness of digital and visual media in sociological teaching and learning. Recent studies evidence that photo essays and blogs are effective teaching tools for engaging students (Andrist et al. 2014; Hoffmann and Hoffman 2006; Sargent and Corse 2013). For instance, students find sociology more relevant when it connects to their own lives and experiences; approaches include using photography to document their everyday lives (Mount 2018), analyzing current events and news using popular media (Stout, Earnhart, and Nagi 2020), and using podcasts (Prince 2020) and other media including YouTube (Belet 2017). These approaches also develop and improve their critical thinking skills (Eisen 2012; Grauerholz and Settembrino 2016; Malcom 2006; Unnithan and Scheuble 1983). Moreover, digital and visual media engages students who have dramatically different learning styles (Pritchard 2013). Scholars have also found blogs to be a useful teaching tool (Davies and Merchant 2009; Pearson 2010), particularly for millennials (Zickuhr 2010). The usefulness of blogs and other social media stems not only from student familiarity, but derives from educational research that point to the importance of context and applicability of concepts, as situated learning theory posits (Lave 1991; McLellan 1996). The use of blogs in this assignment thus encourages "everyday cognition by anchoring knowledge and skill in realistic contexts" (Choi and Hannafin 1995).

The integration of visual sociology with the sociology of teaching and learning has demonstrated the importance of using visuals to communicate information and assist students with applying course materials to their daily lives (Whitley 2013), and such connections to daily life and personal experience enhances the sociological imagination (Mattson 2021). Using visual media is an effective way engage students in courses, with high positive feedback from students 
(Whitley 2013). The Sociological Images blog is a visual web medium that can be a useful teaching tool (McCormack 2011).

Developed by sociologist Lisa Wade of Occidental College, Sociological Images is a blog "presenting brief discussions of compelling and timely imagery that span the breadth of sociological inquiry," (Wade 2015). Anyone may submit images (such as those of advertisements, products, news coverage, music videos, etc.) for inclusion. The blog moderator and guest bloggers write the analysis of images. Posts stimulate the sociological imagination by evoking questions about the distinction between personal troubles and public issues (one of the core learning goals of sociology courses) (McCormack 2011). For instance, a recent post problematizes the presentation of a statistic about terrorism recruitment by state in a news article. The author discusses how it is an example of fear-mongering, exaggerating the incidence of terror recruitment by showing a rate when the actual number of cases is very small (Stewart 2018). The Sociological Images website is a forum for sociological discourse, engaging the public as well as academics from various disciplines. The blog is written in an accessible manner, making it ideal for introductory and lower division courses. Instructors can use the website to introduce sociological concepts through visuals and to stimulate discussion of those concepts. Because of its widespread use and supporting research on effectiveness and interdisciplinary and public engagement, we use this tool in our assignment series to cultivate the sociological imagination.

\section{Assignment SERIES Learning Goals and Description}

The learning goals for this assignment series were to help students develop their sociological imagination through: (1) Applying sociological concepts and theories to real-world events and issues; (2) Seeing sociologically in their own daily lives to distinguish between individual 
troubles and public issues; and (3) Communicating these ideas using both formal written sociological analysis and a popular media format (blog). By using two assignments, we can demonstrate increased student learning that develops from practice and instructor feedback.

The series consisted of: (1) an assignment in which students selected 3 blog posts from the Sociological Images website and expanded on the commentary presented on the blog site, incorporating discussion of sociological concepts and theories learned in our course ${ }^{1}$ and, (2) a final project in which students found three of their own "sociological images," preferably photos taken in their daily lives, and analyzed them using sociological perspectives, theories, and concepts.

The assignment exposed students to existing sociological analysis of images from the Sociological Images website and allowed them to expand on the authors' blogs through discussion of course material. Students were asked to select three blog posts from the Sociological Images website and write an essay in which they provided a concise summary of the blog post, as well as their own expanded analysis of the images. This allowed them to both see how others write from a sociological perspective for a public audience, and also to expand on others' commentary drawing on their knowledge of sociological concepts and theory gained in the course.

The final project built upon the assignment by allowing students to exercise their own imaginations by finding images in their daily lives and writing a sociological analysis of the images in two formats: blog and academic essay. Students could select images from a plethora of sources; examples included ads in magazines (either screenshot online or photo of print), commercials, news video clips, and fliers on campus. The types of images students could use was intentionally left broad in the final project guidelines so that students could use their 
sociological eye in their daily life. For example, one student included a photo of a video game he played, another took a photo of a billboard near campus, and others used screenshots of images on Instagram or other social media sites. In the blog portion of the assignment, students were asked to write a concise piece in which they analyzed the image using major sociological concepts. In the academic essay, students went further in-depth in their discussion of the images, incorporating various sociological theoretical perspectives, drawing links between sociological concepts and theories, and incorporating discussion of other course material (e.g., activities, videos, readings). Students were given the assignment guidelines (see Appendices) and rubric at least two weeks before the assignment and final project were due.

The project series was situated within broader course learning tools, including the use of traditional lecture with Powerpoint; internet examples and videos from the Sociological Images website and other sources; in-class discussion; and, numerous interactive class activities. In the weeks prior to the introduction of the first assignment, the Sociological Images website was used in the class discussions on a weekly basis to introduce and familiarize students with the website, blog style writing, and sociological analysis of "images" drawn from daily life.

\section{RESEARCH METHODS}

The assignment series was tested at a private regional university in the western United States, in six lower division sociology classes, ranging in size from 22 to 34 students, during the fall semesters of three consecutive academic years (2013-2016). The average undergraduate enrollment at the university is between 6,000 and 6,500 students per year. The undergraduate population is predominantly non-Hispanic White (53 percent), followed by Hispanic (15 percent), and Asian (11 percent); approximately 85 percent of students receive financial aid. The series was introduced in two lower division courses, Introduction to Sociology and Social 
Stratification, which fulfill a university General Education requirement of "Social Inquiry;" therefore, a substantial proportion of students were not sociology majors. The inequality course was an elective for majors and minors while the introductory course was a required course. Although we did not systematically collect demographic data, the student composition of the lower division, general education requirement-filling sociology courses largely reflects the broader undergraduate population.

Students signed informed consent forms stating that their assignment series evaluations were going to be used for research purposes; the study was deemed exempt by the Institutional Review Board. Students in six classes also filled out anonymous surveys about their learning in the assignments. Students in an introductory sociology class completed an anonymous pretest survey (also with informed consent) in spring semester 2018 to provide a baseline of students' knowledge related to learning goals. The instructor quantitatively and qualitatively assessed student learning outcomes within the initial assignment and final assignment.

\section{Assessment of Assignment Series Effectiveness}

Pretest. Using a nonequivalent-comparison-group sample $(\mathrm{N}=27)$, we administered a faculty-designed, open-ended survey in an Introduction to Sociology course in 2018; it was given in the second week of a 15-week semester, after the course had covered Mills' sociological imagination and the discipline's major theoretical perspectives. The pretest survey contained four questions based on the assignment series learning goals, to measure sociological knowledge and critical thinking skills. The first question required students to identify an example of society's impact on individuals' lives. The second and third questions offer images (one a chart and the other an advertisement) that students were asked to interpret using sociological concepts or theories. Finally, the students were asked to connect a statistic from the chart to a sociological 
theory. Although it is ideal that pre-post data come from the same student sample, we were unable to administer pretest assessments in the classes in which the assignment series was completed. Nevertheless, our approach is preferable over a no-comparison-groups approach (Sweet and Cardwell 2016).

Instructor assessment. The instructor assessment was guided by rubrics developed based on the project guidelines, which outlined the learning goals. Project and evaluation guidelines were also discussed in-class before each assignment was due. For the first assignment, four broad areas related to the learning goals were assessed: (1) the accuracy of the blog summary; (2) the successful expansion of the blog analysis using appropriate concepts from the course, and depth of discussion; (3) the distinction between the website's and students' own analysis; (4) the clarity and organization of the writing. For the final project, the following aspects were assessed: (1) the appropriateness of the image to the course content and the source (e.g., own photograph versus found online); (2) successful use of sociological concepts and theories to critically analyze images; (3) the ability to write two distinct analyses - one in a concise blog style and the other in academic essay format. Faculty assessment included increased expectations related to students' use of concepts and theories in the second assignment, which encouraged student learning.

Student surveys. Students evaluated the series through an anonymous instructor-generated survey. The survey was administered to students in the six lower division sociology courses where the assignment series was utilized. Students were asked to complete the voluntary, anonymous evaluation in-class on the day they turned in their final projects. Of 157 students enrolled, 113 students completed evaluations, for a response rate of approximately 72 percent (students absent on evaluation day were not surveyed but are included in those enrolled). 
Student evaluations included seven items with a Likert scale of response options, ranging from 1 (strongly disagree) to 5 (strongly agree), and an open-ended comment section. The questionnaire addressed the assignment and final project separately. Questions about both portions of the series asked to what extent the student believed each had aided their learning of course concepts. Additional questions about the first assignment asked whether it helped them see "how sociological concepts are used to explain, in writing, various issues" and "the link between sociological concepts and real-world issues." The final project questions asked students about their agreement with statements about their skills in writing using sociological concepts and their development of a sociological imagination. A final question asked for scaled agreement with the following statement, "It was helpful to complete the assignments prior to doing the final project." In the open-ended section of the evaluation, 57 students offered comments.

Table 1 presents the frequencies and descriptive statistics (mean and standard deviation) for each item and the overall response means. A two-sample Mann-Whitney test showed no significant difference in overall evaluation mean by course (4.63 for introductory sociology versus 4.7 for social inequality, $p=0.72$ ), therefore, we did not disaggregate results by course.

Grades. To assess individual improvement during the series, we also examine assignment and final project grades, specifically the percent of students who performed better on the final project than the assignment, and the percent who received a $\mathrm{B}$ or $\mathrm{C}$ grade (to assess how many students produced "average" work).

\section{FINDINGS}

The nonequivalent-comparison-groups pretest allows us to assess learning by measuring the baseline sociological knowledge of students. Results showed that 20 of 27 students ( 74 percent) 
were not able to answer one or more of the questions (all but one stated they did not know the answer). Although these students had been introduced to the sociological way in a standard lecture-format just prior to the pretest, the majority of students had no sociological imagination. Among those who answered all the questions, most were able to give an example of how society might impact their lives as individuals; however, only two students were successful in applying theory or concepts to analyze the two images presented. This suggests that most students who took the lower division classes in which these assignments are used begin the class with little a priori knowledge related to standard sociological learning goals. Without knowledge of sociological concepts or theories, students could not meet any of the learning goals or successfully complete the assignment and final project. The instructor and student assessment of the assignment series is offered below.

\section{TABLE 1 ABOUT HERE}

\section{Learning Goal 1: Apply Sociological Concepts to the Real World}

Both the assignment and final project addressed this learning goal. In the assignment portion of the series students were asked to choose a blog from the Sociological Images site and expand on the authors' discussion by specifically integrating course content (e.g., concepts and theory, class reading, lecture material, etc.) to discuss the image. It was important to the assignment's success for the professor to explicitly encourage students to choose a post they could expound using sociological concepts and theory that were not addressed in the original post.

For the first assignment, most students successfully used sociological concepts, theories, and data from the readings, to expand on the blog posts. One student successfully met this learning goal by expanding on the post titled, "The Census and the Social Construction of Race." 
The student summarized the argument made in the post and elaborated the reasons why race categories have changed over time. The student noted that racial identification norms are part of American non-material culture, which is shaped by social institutions including a government dominated by whites; the student further described how those with power in government agencies design the census race categories, allowing them to "control how others view themselves, and to legitimize or delegitimize certain racial groups." Students also incorporated information from readings or other class material. One student, for example, referred to an inclass video about economic inequality in his discussion of the American Dream, meritocracy, and conflict theory. As with any assignment, however, some students did not meet the learning goal. A few students felt they did not have much to add to the authors' analysis, and did little more than summarize the blog posts, although this was uncommon.

In the quantitative student evaluation, agreement was strongest with the four statements related to student application of course concepts. Over 70 percent of students "strongly agreed" with the five statements about the course concepts, suggesting that students saw the usefulness of this assignment in learning sociological theory, terms, and data. Strongest agreement was with the statement that the first assignment "helped me see the link between sociological concepts and real-world issues," with 83 percent of students strongly agreeing. Nearly 78 percent of students strongly agreed that the final project helped them to "practice explaining... real world issues using sociological concepts."

In the open-ended comments, numerous students noted that the project made sociology more applicable to real life. For example, a student wrote, "These assignments made sociology more interesting \& relevant because they use issues from recent events.” Other students commented on the applicability of the assignments, with one explaining that this made the 
assignments "more interesting" because "it gave me a chance to apply lessons we learned in the class to real world society—something I don't get very often.” By asking students to relate the concepts to blogs and images that they chose, the assignment brought sociology to life, as one student described, "I really liked how we were able to apply what we learned to the world around us. Everything was reinforced."

Even the few students who expressed having some initial resistance to the project, commented that the assignment series was ultimately helpful. For example, one commented, "At first I was annoyed that we had to do projects but I found them super interesting and enjoyed it a lot." Although some students may believe they prefer exams over written assignments in lower division general education courses, the project series was successful in moving students beyond memorization of concepts and theories to application of those concepts and theories to the world around them.

\section{Learning Goal 2: Seeing Sociologically in Daily Life}

This learning goal was specific to the final project, in which students identified their own images. The following examples illuminate the type of images that students identified as sociologically relevant from their daily lives. One student photographed a campus flier advertising make-overs, which the student used to discuss gendered beauty norms, self-esteem, and increased body image issues among women as a public issue rather than personal trouble. Another student took a photograph in their dormitory of an activity that asked residents to write adjectives about each of their Resident Advisors, which evidenced everyday use of gender dichotomization. In another project, a student photographed a billboard with a restaurant advertisement that featured a photo of a woman and read, "Do you lust for juicy thighs?" That student used this image to discuss sexualization, referring to feminist conflict theories. Projects 
spanned a variety of sociological topics, but a substantial proportion of students chose to focus on gender, perhaps indicating that students have an easier time seeing gender issues than race or other sociological issues.

The most successful projects incorporated an in-depth discussion of sociological concepts and theories, referencing the course readings and class videos, activities, and other assignments, into their analyses of their images from their daily lives. In one particularly successful project, the student photographed a women's magazine article about how menswear on women is en vogue. The student used a conflict theory perspective to discuss how patriarchal definitions of beauty norms impact perceptions of women in the work force. The student successfully integrated concepts such as the glass ceiling, gender dichotomy, and norms of masculinity and femininity, in the academic portion of the final project. The student's blog piece, about the way media continues to privilege masculinity in white-collar work, was well-written and insightful, and was accepted for publication on a sociological website. A separate successful project included a photo of campus art; the student noted, "Thousands of students pass that bust annually without knowing the life and history of [Albert] Schweitzer." Drawing on course readings to discuss the phenomenon of the "white savior," the student described this as an example of "how institutions perpetuate what the authors of the book Seeing White call the hidden curriculum." The student's paper also integrated both macro-theoretical perspectives of conflict theory and structural-functionalism on racial inequality discussed in the course. Despite many students producing successful projects, some students did not adequately incorporate discussion of theoretical perspectives or sufficient concepts from the course into their discussion of their images, which reflected their difficulty in seeing sociologically. 
Most students rated the final project highly for its ability to link sociological concepts to their own lives, with nearly 94 percent agreeing (71 percent strongly agreeing) that it helped them to develop their sociological imaginations (Table 1). Multiple students commented that they appreciated the opportunity to apply a sociological lens to their personal lives. One explained, "I liked the final project more because I got to find my own images and I really felt the impact of my newly formed sociological imagination." Another noted, "Both assignments were extremely helpful in changing how I approach situations. I now approach situations with a sociological imagination."

\section{Learning Goal 3: Write Sociological Analysis for Both Academics and the Public}

Effectively communicating sociological analysis in writing was a key component of both the assignment and final project; however, writing for both academic and public audiences was a learning goal specific to the final project. The two-prong design was intended to give students the opportunity to communicate sociological analysis to two separate audiences: sociologists and a wider public. Writing both a short blog-style piece and an academic essay was the most challenging part of the project for students. Multiple students commented that it was difficult for them to differentiate between the blog and the academic essay, and some students were unsuccessful because they were too repetitive, with a few students even having several sentences (or, in a rare case, an entire paragraph) copied verbatim between the blog and essay.

Despite this challenge, most students were able to successfully write compelling and succinct blog pieces and provide more in-depth, academic analysis in the essay portion. One successful project examined how racial/ethnic and gender stereotypes are used in marketing, using an image from a cosmetic treatment advertisement. In the blog portion, the student wrote, "Not only does the ad begin with the 'youthful skin stereotype,' it then paints Asian women with 
another stereotype, that of stoic shamans with 'ancient Chinese secrets."' In the essay portion, the student elaborated by connecting all three images in the thesis statement, "The following advertisements illustrate the prevalence of gender and racial inequality in the social institution of media, through objectification, stereotype, and use of the gender binary. Together, these images can also be seen as an exemplification of the conflict perspective." This student successfully wrote both a blog, which conveyed the main point about social inequality in the media in language accessible to a broad public, and an academic essay that integrated scholarly sources and theoretical perspectives.

Another student examined racism in a popular video game. In the blog, the student wrote, "It's no secret that the video game industry caters to white men, but most video games are subtle about their racial prejudice... Dark Souls actually provides us with fictional races of people... Notice that the 'Commoner' is just a 'typical' white man. Dark Souls sets white skin as normative, so that race is nearly invisible." In the essay portion, the student then explicitly discussed concepts from the reading, including racial blindness privilege, stereotyping, and meritocracy. While the blogs succinctly analyzed the sociological meaning of an image, the essay delved further into explanations for the phenomenon identified using additional sociological theories and concepts. Essays not only incorporated more course concepts, but writing was expected to be more formal and for a higher grade-level.

Student evaluations indicated that students strongly believed that the final project helped them to write about sociological issues. Over 96 percent of students agreed with the statement, "Final Project helped me to practice explaining, in writing, real world issues using sociological concepts.” In the open-ended evaluation students also described their writing, and students particularly enjoyed the blog-style writing element. For example, one commented, "Writing our 
own blogs was an especially helpful exercise, because it challenged me to be original \& critical!" Comments such as this indicate that students find value in the expectation to explain sociological concepts in lay language.

\section{Student Grades: Learning Over Time}

Examining grades for this assignment series provides a quantitative assessment of student performance to corroborate the qualitative instructor assessment. Across the six courses, 39 percent of students received a grade of "B" or "C" on the assignment, while for the final project, it was 60 percent. To better assess student learning resulting from completion of the assignment series, we calculated the percent of students whose grade on the final project was either the same or improved compared to the assignment grade. We found that 50 percent improved, with a mean increase of 1 percentage point. This grade comparison does not account for the fact that the instructor's expectations were higher for the final project (and therefore, grading more stringent) because students were being assessed on cumulative knowledge gained during the semester; thus, the magnitude of learning between the assignment and final project is underestimated.

Suggestions for using this ASSIGNMENT series. Overall, the assignment series was successful in helping students meet the learning outcome goals for these introductory courses. Based on our experience, we provide several suggestions for additional tailoring of the assignment series based on student feedback and instructor assessment. First, an important addition to this project would be a pretest administered at the start of class to one section that uses this assignment and another with an assignment focused on other goals; both would be given an end-of-the-semester posttest. This would allow the instructor to assess baseline knowledge and verify learning after completion of the assignments (Sweet and Cardwell 2016). 
Second, there are several ways the assignment could be reduced should an instructor wish to use only a portion of the series. Obviously, instructors could use only the initial assignment or the final project. Although several students noted that doing the assignment prior to the final project was useful review and practice, some noted that the final project was most useful and interesting. Upper-level courses may be able to use the final project successfully without the first assignment. Another option may be to reduce the number of required images from three, so that the student discussions are more targeted and in-depth. A third option for reducing the assignment also addresses the issue that some students found it challenging to write both a blog piece for each image and an academic essay synthesizing all images; instructors might decide whether a blog format or academic essay is most appropriate in meeting their course learning goals and only ask for that option for the final project.

Finally, some modifications may help instructors tailor the series to their own needs. To encourage a more active class discussion around sociological issues and deepen students' engagement in public sociology, students can be asked to post the blog portion of their final projects to a class website, such as Blackboard Blog or even a public blog using WordPress or Weebly. Students could then comment on peers' photos and analysis and contribute to the social construction of knowledge. In terms of student expectations, instructors may wish to provide more specific criteria and rubrics tailored to their course learning goals. The guidelines and rubric can specify how many concepts students should discuss, whether incorporating discussion of theory is expected, to what extent other class material should be discussed, and what specific types of images are appropriate. For instance, in courses with a greater focus on theory, the rubric can specifically address the expectations for theoretical analysis. Moreover, the guidelines for both the assignment and final project could be provided to students simultaneously so that 
students could have a better grasp on the overall purpose of the assignment series and the learning outcomes. Lastly, the assignment due dates can be spaced further to reduce the grading burden on the instructor.

Instructors may also choose to be explicit in the project guidelines about what types of images are acceptable; that is, whether students must take their own photographs. In order for students to exercise their sociological imaginations, it is important to have students use images they found in their own lives (e.g., screenshot from Instagram or Twitter or a photo taken with their phone), rather than using images found on the internet by searching for terms such as "gender inequality" or "objectification." In the first iteration of this assignment some students used images from the internet rather than taking photos themselves, and this made it more difficult to discern whether students plagiarized parts of their analysis from internet sources. The second and third years of project implementation corrected this by stating clearly in the final project guidelines that images from online would need to be screenshots and sources noted.

This project series can also be tailored to a variety of more specialized sociology courses. First, it can be tailored by including guidelines for topics; for example, a gender course could require that images or analyses must address gender inequality or norms, and for a stratification course the guidelines could require images related to economic and/or racial inequality. Another approach might be to integrate a historical perspective, another facet of the sociological imagination, as an explicit component of the assignment. Students tended to use contemporary images in this project series, but by encouraging a historical perspective, students could be asked to consider how cultural phenomenon, societal trends, etc., have led to the issue their image captures. Another option would involve a comparative approach in which students would access the growing number of digital archives available to locate a historical image to pair with a 
contemporary image on the same topic; for example, one might examine the social construction of masculinity by comparing an advertisement for boys' fashion from today with one from a previous era.

In addition to sociology courses, this project could be tailored for use in other social settings. For instance, it could be used in teacher trainings to help develop educators' ability to place their classroom experiences in broader social structural context. It could also be used for in a health care setting to help workers see the impact of social factors, such as family background, culture, and socioeconomic status, on individual health behaviors and outcomes.

\section{CONCLUSION}

As scholars have noted, encouraging the development of students' sociological imaginations is no easy task (Dandaneau 2009). This two-part assignment series develops students' sociological imaginations by, first, engaging with a public sociology blog and applying sociological concepts and theories to images, and then challenging students to identify and analyze things they see in their daily lives using sociological concepts and theories. In completing this series, students worked toward three learning goals core to sociology: applying sociological concepts to the real world, seeing sociologically in their daily lives, and writing about sociological concepts in a way that is relevant to a broader audience.

This novel assignment series contributes to the scholarship of teaching in learning in several ways. First, it builds on existing valuable knowledge about image-based assignments (Whitley 2013), showing that students understand sociological concepts and theories better when they are asked to apply them to images from their daily lives. Second, the series challenges students to practice both formal and informal writing as a means of developing higher-level 
thinking skills (Massengill 2011) and practicing public sociology. The two forms of writing supported student development in formal writing and in applying sociology to more casual and interactive forms of writing such as blogs.

Through this assignment series, students engaged in several exercises that Mills (1959) suggested can stimulate the sociological imagination: (a) classifying and cross-classifying ideas, (b) inverting one's sense of proportion, and (c) writing in a clear, accessible manner and avoiding "socspeak." First, students practiced classifying and cross-classifying by analyzing multiple images for substantive links or differences between them. Second, students practiced inverting their sense of proportion in this project by striving to recognize broader macrostructural issues in their daily lives where they usually are imperceptible, or seemingly minute. In discussing how to invert the sense of proportion, Mills suggested, "If something seems very minute, imagine it to be simply enormous, and ask yourself: What difference might that make?" (Mills 1959:215). Students practiced this switch in perception when they are challenged to identify and analyze sociologically relevant phenomena in their daily lives. Finally, students practiced writing in a clear, accessible manner in the blog portion of the assignment series.

While engaging students' sociological thinking is crucial, it is also important for them to share their skills with a broad audience given the recent calls for sociologists to engage in public discourse (Patterson 2014), a call repeated in other disciplines (Kitchin et al. 2013; Kouper 2010). Strengthening student skills in communicating sociological analysis to multiple audiences responds directly to these recent calls, and blog formats are one way to participate in public sociology (Wade and Sharp 2013). In order to help students translate what they have learned in their sociology courses, the final project requires students to write in a format suitable for a blog in addition to a format suitable for a college-level academic essay. Although many assignments 
ask students to engage in using their sociological imagination in essays (Dandaneau 2009), the blog-style writing element encourages students to find ways to incorporate their sociological imaginations into everyday communication with others. Since most students who take lowerlevel sociological courses to meet general education requirements, will not take further sociology courses, this skill will serve them well as engaged citizens. This approach also responds to Mills' criticism of academic work that uses exclusionary jargon, or "socspeak" (Mills 1959:220). Writing blogs in addition to an academic essay not only allows students to reach the learning goals related to students' own understanding, but to share their insights and practice engaging in the public sphere.

Our assessments contribute to the mounting evidence that digital and visual media are effective tools to help meet sociology learning goals. After using this series with over 150 students, we believe that digital and visual assignments such as this one can be a valuable starting point in developing the sociological imagination. Exposing students to accessibly written sociological analysis of timely topics, challenging students to find visual examples of sociological concepts in their daily lives, and to write their own sociological analysis in both an academic and more accessible style may help bridge the disconnect between classroom discussions of sociology and the "real world." Moreover, similar to Pelton's (2012) findings regarding use of films, we found that the use of images helped students understand theories and concepts more concretely and apply sociological analysis to their daily lives.

The assessments provided here (pretest data on non-comparable group, instructor qualitative and quantitative assessment, and student evaluations of learning) go beyond the commonly used evidence of effectiveness. However, these assessments are not sufficient for establishing the causal effect of the assignment series on learning. Future studies should collect 
pre- and post-test data, and ideally include a control group (Sweet and Cardwell 2016).

Nevertheless, students' evaluations of these assignments revealed enthusiasm for the assignment series and agreement that it was an effective learning tool. Pre-test data showed that students do not have the ability to analyze images from a sociological perspective early in the semester. Importantly, the instructor's assessment corroborates students' evaluations, indicating that the majority of students who produced these assignments not only understand the concept of the sociological imagination but also develop their own sociological imaginations.

In completing this project series, students developed not only their sociological imagination both also their writing skills and ability to communicate sociology to both academic and public audiences — an important element distinguishing the social scientist from the "mere technician" (Mills 1959). The ability to see the impact of broader social forces on individual lives is a crucial element in the training of the next generation of social scientists. Thus, we encourage sociology instructors to adapt this project to their own course learning goals, and to embrace the increasing digital and visual media tools available to develop students' sociological imaginations. Given the challenges that the COVID-19 pandemic created for face-to-face learning, it is important to note this assignment could be achieved in a classroom that is virtual or in-person.

\section{ACKNOWLEDGEMENTS}

We are grateful to the students who completed this assignment series and provided feedback. We also thank the editor and anonymous reviewers for their feedback. 


\section{NOTES}

${ }^{1}$ The first time this assignment series was used in a course, students completed the assignment twice (on different topics) before completing the final project. Student feedback indicated that the second assignment was redundant, so in subsequent courses, only one assignment was completed before the final project. 


\section{REFERENCES}

Andrist, Lester, Valerie Chepp, Paul Dean, and Michael V. Miller. 2014. "Toward a Video Pedagogy: A Teaching Typology with Learning Goals." Teaching Sociology 42(3):196206. doi: $10.1177 / 0092055 \times 14524962$.

Belet, Margot. 2017. "The Importance of Relevance to Student Lives: The Impact of Content and Media in Introduction to Sociology." Teaching Sociology 46(3):208-24. doi: 10.1177/0092055X17730113.

Bidwell, Lee D. Millar. 1995. "Helping Students Develop a Sociological Imagination through Innovative Writing Assignments." Teaching Sociology 23:401-06. doi: 10.2307/1319169.

Bonwell, Charles C., and James A. Eison. 1991. "Active Learning: Creating Excitement in the Classroom. 1991 Ashe-Eric Higher Education Reports."

Brouillette, John R, and Ronny E Turner. 1992. "Creating the Sociological Imagination on the First Day of Class: The Social Construction of Deviance." Teaching Sociology 20(4):276-79.

Choi, Jeong-Im, and Michael Hannafin. 1995. "Situated Cognition and Learning Environments: Roles, Structures, and Implications for Design." Educational Technology Research and Development 43(2):53-69. doi: 10.1007/BF02300472.

Dandaneau, Steven P. 2009. "Sisyphus Had It Easy." Teaching Sociology 37(1):8-19. doi: 10.1177/0092055X0903700102.

Davies, Julia, and Guy Merchant. 2009. "Negotiating the Blogosphere: Educational Possibilities " in Digital Literacies: Social Learning and Classroom Practices, edited by Carrington, V. and M. Robinson. London: SAGE. 
Eisen, Daniel B. 2012. "Developing a Critical Lens: Using Photography to Teach Sociology and Create Critical Thinkers." Teaching Sociology 40(4):349-59. doi: $10.1177 / 0092055 \times 12448322$.

Ferguson, Susan J., and William Carbonaro. 2016. "Measuring College Learning in Sociology." Pp. 125-87 in Improving Quality in American Higher Education: Learning Outcomes and Assessments for the 21st Century, edited by Arum, R., J. Roksa and A. Cook. San Francisco: Jossey-Bass.

Ghidina, Marcia. 2019. "Deconstructing Victim-Blaming, Dehumanization, and Othering: Using Empathy to Develop a Sociological Imagination." Teaching Sociology 47(3):231-42. doi: 10.1177/0092055X19843978.

Gillis, Alanna, and Laura M. Krull. 2020. "Covid-19 Remote Learning Transition in Spring 2020: Class Structures, Student Perceptions, and Inequality in College Courses." Teaching Sociology 48(4):283-99. doi: 10.1177/0092055X20954263.

Grauerholz, Elizabeth, and Marc Settembrino. 2016. "Teaching Inequalities: Using Public Transportation and Visual Sociology to Make It Real." Teaching Sociology 44(3):20011. doi: $10.1177 / 0092055 \times 16644658$.

Greenberg, Miriam, Rebecca London, and Steve McKay. 2019. "The Vitality of Students for Public Sociology." Contexts 18(4):60-60. doi: 10.1177/1536504219883859.

Hoffmann, Elizabeth A., and Elizabeth A. Hoffman. 2006. "The Importance of Place: Using Local-Focus Videos to Spark the Sociological Imagination." Teaching Sociology 34(2):164-72.

Hudd, Suzanne S. 2012. "Writing Sociology: Practices of a Discipline." Teaching Sociology 41(1):2-4. doi: 10.1177/0092055X12471820. 
Huisman, Kimberly. 2010. "Developing a Sociological Imagination by Doing Sociology: A Methods-Based Service-Learning Course on Women and Immigration." Teaching Sociology 38(2):106-18. doi: 10.1177/0092055x10364013.

Kitchin, Rob, Denis Linehan, Cian O'Callaghan, and Philip Lawton. 2013. "Public Geographies through Social Media." Dialogues in Human Geography 3(1):56-72. doi: $10.1177 / 2043820613486432$.

Kouper, Inna. 2010. "Science Blogs and Public Engagement with Science: Practices, Challenges, and Opportunities." Journal of Science Communication 9(1). doi: https://doi.org/10.22323/2.09010202.

Kozimor, Michele Lee. 2020. "Editor's Comment: Three Teaching Takeaways from the Covid19 Pandemic." Teaching Sociology 48(3):181-83. doi: 10.1177/0092055X20931953.

Lave, J., \& Wenger, E. . 1991. Situated Learning: Legitimate Periperal Participation. Cambridge, UK: Cambridge University Press.

Malcom, Nancy L. 2006. "Analyzing the News: Teaching Critical Thinking Skills in a Writing Intensive Social Problems Course." Teaching Sociology 34(2):143-49. doi: $10.2307 / 20058469$.

Massengill, Rebekah Peeples. 2011. "Sociological Writing as Higher-Level Thinking: Assignments That Cultivate the Sociological Imagination." Teaching Sociology 39(4):371-81. doi: 10.1177/0092055X11407350.

Mattson, Greggor. 2021. "Responding to Wobbly Classrooms through Scaffolded, Peer-Led, Small-Group Presentations of Personal Learning Goals: The Beyond the Book Tool." Teaching Sociology 49(2):162-72. doi: 10.1177/0092055X21991628. 
Mayeda, David T. 2010. "Review of Sociological Images." Teaching Sociology 38(4):401-03. doi: $10.2307 / 27896565$.

McCormack, Karen. 2011. "Sociology in the Blogosphere? Exploring Sociological Images." Visual Studies 26(2):169-73. doi: 10.1080/1472586x.2011.571896.

McKinney, K., C. Howery, K. Strand, E. Kain, and C. Berheide. 2004, "Liberal Learning and the Sociology Major Updated: Meeting the Challenge of Teaching Sociology in the TwentyFirst Century " A Report of the ASA Task Force on the Undergraduate Major, Washington, D.C. http://www.asanet.org/documents/teaching/pdfs/Lib_Learning_FINAL.pdf.

McLellan, Hilary. 1996. Situated Learning Perspectives. Englewood Cliffs, NJ: Educational Technology Publications.

Mills, C. Wright. 1959. The Sociological Imagination. New York, NY: Oxford University Press. Mount, Liz. 2018. "Teaching in Unfamiliar Terrain: Empowering Student and Teacher Learning through a Photography Assignment." Teaching Sociology 46(1):54-61. doi: 10.1177/0092055X17725131.

Noy, Shiri, and Megan Hancock. 2020. "Teaching International Development Locally: Using Museum Collections to Ground Students' Learning." Teaching Sociology 49(1):32-44. doi: $10.1177 / 0092055 X 20966719$.

Patterson, Orlando. 2014. "How Sociologists Made Themselves Irrelevant." The Chronicle of Higher Education. The Chronicle Review, Dec. 1, 2014 http://chronicle.com/article/HowSociologists-Made/150249/.

Pearson, A. Fiona. 2010. "Real Problems, Virtual Solutions: Engaging Students Online." Teaching Sociology 38(3):207-14. doi: 10.1177/0092055x10370115. 
Pelton, Julie A. 2012. "“Seeing the Theory Is Believing”: Writing About Film to Reduce Theory Anxiety." Teaching Sociology 41(1):106-20. doi: 10.1177/0092055X12462142.

Perrin, Andrew. 2015. "Social Media Usage: 2005-2015." Internet, Science \& Tech.

Persell, Caroline Hodges. 2010. "How Sociological Leaders Rank Learning Goals for Introductory Sociology." Teaching Sociology 38(4):330-39. doi: $10.1177 / 0092055 \times 10378822$.

Pike, Diane L., Teresa Ciabattari, Melinda Messineo, Renee A. Monson, Rifat A. Salam, Theodore C. Wagenaar, Jeffrey Chin, et al. 2017. "The Sociology Major in the Changing Landscape of Higher Education: Curriculum, Careers, and Online Learning. A Report of the ASA Task Force on Liberal Learning and the Sociology Major." American Sociological Association.

Prince, Barbara F. 2020. "Podcasts: The Potential and Possibilities." Teaching Sociology 48(4):269-71. doi: 10.1177/0092055X20959837.

Pritchard, Alan. 2013. Ways of Learning: Learning Theories and Learning Styles in the Classroom. NY, NY: Routledge.

Rogers, Kimberly B., Adam Nemeroff, and Kelly Caputo. 2019. "Strategic Design toward Foundational Learning Goals in Introduction to Sociology." Teaching Sociology 48(1):40-53. doi: 10.1177/0092055X19872789.

Sargent, Carey, and Sarah M. Corse. 2013. "Picture My Gender(S): Using Interactive Media to Engage Students in Theories of Gender Construction." Teaching Sociology 41(3):242-56. doi: $10.1177 / 0092055 \times 13480050$. 
Scanlan, Stephen J., and Liz Grauerholz. 2009. "50 Years of C. Wright Mills and the Sociological Imagination." Teaching Sociology 37(1):1-7. doi: 10.1177/0092055X0903700101.

Stewart, Evan. 2018. "What's That Fact? A Tricky Graph on Terror." Sociological Images (blog) The Society Pages, Feb. 12, 2018 https://thesocietypages.org/socimages/2018/02/12/whats-that-fact-a-tricky-graph-onterror/.

Stout, Vanessa, Eric Earnhart, and Mariam Nagi. 2020. "Teaching Race and Ethnicity in the Age of Trump: Using Popular Culture in a Polarized Classroom." Teaching Sociology 48(3):220-30. doi: 10.1177/0092055X20928469.

Sweet, Stephen , and Marissa Cardwell. 2016. "Editor's Comment: Considering Assessment." Teaching Sociology 44(3):149-50. doi: 10.1177/0092055X16650659.

Trautner, Mary Nell, and Elizabeth Borland. 2013. "Using the Sociological Imagination to Teach About Academic Integrity." Teaching Sociology 41(4):377-88. doi: doi:10.1177/0092055X13490750.

Unnithan, N. Prabha, and Laurie K. Scheuble. 1983. "Evaluating an Attempt at Relevance: The Use of News Item Analysis in Introductory Sociology." Teaching Sociology 10(3):399_ 405. doi: $10.2307 / 1317368$.

Wade, Lisa. 2015. "Sociological Images." Sociological Images The Society Pages, 8/19/2015 http://thesocietypages.org/socimages/about/.

Wade, Lisa, and Gwen Sharp. 2013. "Sociological Images: Blogging as Public Sociology." Social Science Computer Review 31(2):221-28. doi: 10.1177/0894439312442356. 
Whitley, Cameron T. 2013. "A Picture Is Worth a Thousand Words: Applying Image-Based Learning to Course Design." Teaching Sociology 41(2):188-98. doi: $10.1177 / 0092055 \times 12472170$.

Zickuhr, Kathryn. 2010, "Generations 2010", Washington, DC: Pew Research Center. https://www.pewresearch.org/internet/2010/12/16/generations-2010/. 


\section{TRAILS RESOURCE}

Bostean, Georgiana, and Lisa Leitz. 2021, "Using Sociological Images to Develop the Sociological Imagination" Teaching Resources and Innovations Library for Sociology: American Sociological Association. http://trails.asanet.org/Pages/Resource.aspx?ResourceID=13994.

\section{AUTHOR BIOGRAPHIES}

Georgiana Bostean is an Associate Professor in the Sociology Department and Environmental Science and Policy Program at Chapman University. She teaches courses including Quantitative Data Analysis, Geographic Information Systems, and foundational courses including Introduction to Sociology. Her research examines social determinants of health, with a focus on population health disparities.

Lisa Leitz is the Delp-Wilkinson Professor of Peace Studies and Associate Professor of Sociology at Chapman University. She is the Editor of the peer-reviewed series Research in Social, Movements, Conflicts and Change and the author of Fighting for Peace: Veterans and Military Families in the Anti-Iraq War Movement. 
Table 1. Student evaluations of assignment series $(N=113)$

The assignment helped me to...

Item 1: Think about the concepts learned in this course.

Item 2: See how sociological concepts are used to explain, in writing, various issues.

Item 3: See the link between sociological concepts and real world issues.

\section{Final Project helped me to...}

Item 4: Think about the concepts learned in this course.

Item 5: Practice explaining, in writing, real world issues using sociological concepts.

Item 6: Develop my sociological imagination.

\section{Overall,}

Item 7: It was helpful to complete the

assignment prior to doing the final project

Item

mean

(sd)

Item response frequency

\begin{tabular}{|c|c|c|c|c|c|c|c|c|c|c|}
\hline & \multicolumn{2}{|c|}{$\begin{array}{l}\text { Strongly } \\
\text { Agree }\end{array}$} & \multicolumn{2}{|c|}{$\begin{array}{c}\text { Somewhat } \\
\text { Agree }\end{array}$} & \multicolumn{2}{|c|}{ Neutral } & \multicolumn{2}{|c|}{$\begin{array}{l}\text { Somewhat } \\
\text { Disagree }\end{array}$} & \multicolumn{2}{|c|}{$\begin{array}{l}\text { Strongly } \\
\text { Disagree }\end{array}$} \\
\hline & percent & $n$ & percent & $n$ & percent & $n$ & percent & $n$ & percent & $n$ \\
\hline $\begin{array}{l}4.6 \\
(.62) \\
4.7\end{array}$ & 70.5 & 79 & 23.2 & 26 & 2.7 & 3 & 1.8 & 2 & 0 & 0 \\
\hline $\begin{array}{l}(.63) \\
4.8\end{array}$ & 73.2 & 82 & 20.5 & 23 & 3.6 & 4 & 1.8 & 2 & 0 & 0 \\
\hline$(.65)$ & 83.0 & 93 & 11.6 & 13 & 0.9 & 1 & 3.6 & 4 & 0 & 0 \\
\hline $\begin{array}{l}4.7 \\
(.54) \\
4.7\end{array}$ & 74.3 & 84 & 22.1 & 25 & 1.8 & 2 & .90 & 1 & 0 & 0 \\
\hline $\begin{array}{l}(.57) \\
4.6\end{array}$ & 77.9 & 88 & 16.8 & 19 & 3.5 & 4 & .90 & 1 & 0 & 0 \\
\hline (.67) & 70.8 & 80 & 23.0 & 26 & 3.5 & 4 & 0 & 0 & .9 & 1 \\
\hline $\begin{array}{l}4.5 \\
(.84)\end{array}$ & 67.9 & 76 & 21.4 & 24 & 6.3 & 7 & 1.8 & 2 & 1.8 & 2 \\
\hline
\end{tabular}

Notes: Data come from students in six lower division sociology classes at a private regional university (2013-2016). Response options for each item were coded 1 (strongly disagree) to 5 (strongly agree). 